\title{
Spirituality as Foundation for Adolescents' Socialisation: Methodological Approaches
}

\author{
Elvyda Martišauskienè
}

Lithuanian University of Educational Sciences, Faculty of Education, Department of Education, Studentų St. 39, LT-08106 Vilnius, Lithuania, martisauskiene@gmail.com

Abstract. The article discusses socialisation problems from the methodological perspective, which are of particular importance in adolescence because this period is closely linked with the most important process, i.e., search for own identity. Therefore, the focus is laid on the inborn powers of individuals, their functions and the role of spiritual dimensions based on transcendence and conscience while creating relations with others and oneself in real and virtual spaces is highlighted as well as spiritual values, as foundation of relations, and adolescents' attitude towards them, which open up access to spirituality education and socialisation.

Keywords: adolescent, socialisation, search for identity, human dimensions, spirituality, values.

\section{Introduction or origins of contemporary challenges of socialisation}

The existence of a human being is based on socialisation, which is encoded as early as in 'The Book of Genesis': "It is not good that the man should be alone" (Gen 2, 18). The history of humankind is pervaded by processes of socialisation, which ensure becoming of a human being. They crystallised into a separate phenomenon only in the 19th century and currently implicate an interdisciplinary nature that links science about a human being and surrounding environment because socialisation is said to be a process, when "an individual integrated into society and its structures $\langle\ldots$. , adopts their accumulated experience, social values and norms, forms socially relevant features of personality" (Juodaityte, 2002, p. 38). Rapid changes in social structures, the scope of research on socialisation has been increasing: attempts are made to penetrate into its (socialisation) fundamental essence, i.e., into becoming of an individual as a personality; focus is laid on problems of socialisation, which more and more frequently emerge in various social strata, groups, regions on the basis of age, gender, nationality and others; the main axes 
of socialisation are analysed, which embrace processes of human adaptation and interiorisation and emerge naturally or are deliberately and purposefully organised (usually at institutional level), etc. The growing extent of socialisation problems is becoming an important challenge to representatives of various areas of sciences and politicians. Therefore, it is important to understand the origins of this breakthrough.

A deeper penetration into the development of society reveals that the socialisation problems of the 21st century mostly occur because of abrupt development of surrounding environment, when an individual enters a distant or even more, a virtual space, the world loses the importance of local gravitation together with generally accepted norms and values, which have been presupposed by this gravitation, polished and purified over centuries and have undergone comprehensive testing. Therefore, the foundations of personality are also shaken, which, as it is widely known, are based on values. Naturally, the more essential their link with the human origin is, the more considerable the effects on the becoming of the personality and its socialisation not only in local but also in global environment are observed. However, post-modern world, which is in constant search for reference points in constant change, finally finds them in the so-called "snapshots", i.e., in relative values, which neither necessitate penetration into their origin, nor require to lay any expectations regarding universality and future perspective. Moreover, they are free from the moral dimension, which would be contrary to change in its own way. Even though the category of honour has been still functioning in the present world (moral education, a moral individual, etc.), the concept of virtue is most frequently applied only in confessional practice, whereas in secular environment it is replaced by the concept of value creating conditions for elimination of the essential content, which, according to philosopher A. Jokubaitis (2012), may turn into the contradistinction, i.e., into terrorism of values. Thus, it can be stated that the "bang" of the environment in the several last decades has expanded the space of the environment within the reach of an individual, which is of importance to him or her (horizontal trajectory) and has approximated it to the field of global problems simultaneously flattening the in-depth one (vertical trajectory based on the becoming of a personality), which essentially predetermine the functioning of the first because it lays foundations for relations. Therefore the range of the latter has remained stable, whereas challenges of socialisation penetrate into all the spheres of human existence particularly strengthening its position in the plane of (self-)education, which targets at purposeful pedagogical assistance.

The article discusses problems of adolescents' socialisation in the pedagogical context. They are of utmost importance because adolescence is the period when young people are provided with new opportunities to authentically identify themselves with environment as well as to engage in processes of socialisation. The problems are encountered, when these processes do not emerge naturally. Then pedagogical (organised) support is the Ariadne's thread, which, as practice shows, frequently fails to ensure the intended outcomes. This aspect is under-researched and, therefore, the following problem question is raised: 
where exactly pedagogical support should be directed to ensure support to adolescents in complicated socialisation processes and to enable their positive involvement.

The goal of the article is to reveal fundamental links of spirituality with adolescents' socialisation.

The following objectives have been set: 1) to determine the concept of spirituality; 2) to highlight the deep link between adolescents' spirituality and socialisation.

The methodology of the research. The article is based on:

- existentialism philosophy and existential psychology about universality and immutability of the essence of an individual, i.e., common peculiarities of all people; about transcendental essence of individual's spiritual dimension;

- humanist psychology, which analyses aspects of authenticity, uniqueness and self-expression of a personality and prerequisites for improvement;

- pedagogical anthropology, which embraces holistic expression of an individual as a subject of physical, psychical and spiritual spread in the process of (self-)education.

The methods of the research: systemic-analytical-comparative analysis of scientific literature and empiric research on the becoming of a personality and processes of adolescents' socialisation; research on adolescents' values employing M. Rokeach's methodology; statistical analysis (SPSS programme), which contributed to establishment of statistical frequencies.

The organisation of the research. The research was carried out in 7th-12th forms in schools of various types (general education and arts schools, Jesuit gymnasiums, real gymnasiums, humanities-oriented gymnasiums) in Vilnius and Kaunas cities and districts in 1999 and in 2009 and its sample included 1257 and 904 respondents respectively. The same schools were chosen for the second research to ensure as close socio-pedagogical situation in all the surveys as possible. Attempts were made to retain similar numbers of learners from 7 th, 8 th and 9 th forms. The distribution according to gender was accidental.

\section{Framework of spirituality}

Penetrating into human socialisation, it can be firmly stated that people of all the generations have been undergoing these processes. They are likely to be essentially related to the human origin, which is still under the veil of mystery in the 21st century. The representatives of various spheres of science, who have revealed numerous secrets of the Universe and disclosed the structure of human genome, have failed to find a unanimous answer to the question where the essence of human origin is as they base cognition of positivism, which "states that invisible does not exist. From the scientific point of view, it is unjustified because a human being cannot firmly state what can be "seen" and what is "invisible" (Einšteinas, 2002, p. 218).Therefore, it is difficult to "scientifically" determine what a human being is and how $\mathrm{s} /$ he differs from animals, even not to confuse 
definitions of an individual and a person and others. It is equally complicated to accept "non-scientific" opinions about the human entity grounded on feeling, experience, the Annunciation and others. It is believed that deeper penetration into natural powers may lead to a better perception of the becoming of a human, where a considerable role is played by socialisation processes.

Approaching the human origin, it should be noticed that not only priests perceive that "a human being is an intersection of three layers of human entity: physical, psychical and spiritual" (Franklis, 2007, p. 342) and that corporal reactivity, psychical emotiveness and spiritual transcendentality intertwine in it and only their aggregate may represent a human being. However, the key role is ascribed to the soul because "spiritual dimension is only characteristic of a human being, therefore it is the real dimension of human entity" (Franklis, 2007, p. 346), which presupposes the structure of a person to a human being, that is, the power to be the subject of own action, what, according to K. Wojtyła (1997) means possessing and managing oneself. Therefore, a person, the Self, is able to determine and to be responsible because "rational and free will derives from the spiritual entity" (Lobato, 2001, p. 67) or to feel needs, which cannot be satisfied by earthly things, and in this may to direct the thought to the reality of supernatural world and existence of eternal values (Collins, 2008) as well as to act self-dependently as "body is an opportunity to realise the soul" (Lobato, 2001, p.63), whereas "touching the supreme, spiritual values in exalts the body and its all needs in a wonderful manner" (Maslow, 1997, p. 207) and others. In other words, a person, as a spiritual creature, not only implies the unity and aggregate of human powers but also establishes this unity and aggregate "because the unity of human entity is determined by the soul and spiritual origin" (Wojtyła, 1997, p. 234). Finally, in the context of all powers, that is, human encounters himself, spiritual and psycho-physical dimension separates" (Franklis, 2007, p. 343), and may be experience in the empiric plane as well. Such capacity of soul evidences transcendental powers. The aforesaid researcher notices that "a human being is human to the extent to which he perceives himself in the face of transcendence; moreover, he is a personality only to extent to which he is personalised in its face, to degree he is transfused with the call of transcendence. This call is testified through conscience" (ibidem, p. 344).

Accepting the attitude of the aforesaid and other authors (Allport, Kaganas, Kuzmickas, Maceina, Jovaiša, Bitinas, Aramavičiūtè, Laumenskaite, Verbylaitè and others) towards the spiritual dimension of a human being, it is necessary to understand the modal expression of spiritual powers. Transcendence serves as foundation, which presupposes person's freedom and it empowers him or her to create own life and authentic relations regardless any circumstances. Moreover, "an individual recognises own uniqueness and oneness only in relation with another individual, who is the same as s / he is" (Laumenskaite, 2006). According to J. Pieperis (1992), "the essence of the soul is characterised not through the feature of intangibility but rather through its quality of being primary: that is the power of interaction, which targets the totality of the being. $<\ldots>$ The origin of the 
soul is based on understanding that world is the field of its relations; the soul has the world rather than the environment" (1992, p. 26) (highlighted by the author). Therefore, the scale of relations may be very broad but the relations with subjects (intra- and inter-subjective) become fundamental in the context of socialisation, according to M. S. Kagan; with subjectivised objects (values), which show, what they mean to an individual as an aggregate; with objectivised subjects (culture), which reveal objectivised expression of the soul of individual creators or their groups, social strata or epochs.

It is undoubted that all the personal relations deriving from the spiritual being, in whatever form, should have only one foundation, which is perceived by some researchers (Maslow) as factor $\mathrm{G}$ (general) or seen in the phenomenon of conscience by researchers in various spheres (Wojtyła, Franklis, Covey, etc.). Following the idea that conscience "reaches the ontological fact of individual's self-realisation through an action", an individual "may go through realisation or, so to speak, may not" (Wojtyła, 1997, p. 203), may not relate to conscience or disclose spiritual potentiality because "the essence of the function of conscience consists of definition of the real good in action and formation of obligation, which corresponds to this action. Obligation is an experiential form of dependence on the true, which is subject to person's liberty" (ibidem, p. 205). Without even penetrating into the philosophical or psychological insights into the phenomenon of conscience, it is obvious that the main function of conscience is "to ensure that an action depends on the cognised truth" (ibidem, p. 205). Therefore, the parameter of the value of relations rests on the embodiment of the true in them, whereas the spread of the soul acquires a reliable criterion, which substantiates the liberty of an individual: "and the truth will set you free" (John, 8:32) because only when linked to the truth "liberty is $\langle\ldots\rangle$ the essence of an individual's becoming Human, the process of creating himself or herself $s$ well as own social life and culture" (Čavčavadze, cited in M. S. Kagan, 1988, p. 96). However, when not based on the truth, liberty becomes its perverted version, an instrument of human destruction, misrule and violence in whatever context and to whatever extent (person, group, family, corporation, party and state, etc.) it is realised or interpreted. According to Augustine, "states without justice are only big gangs of robbers" (cited in Pieperis, 1992, p. 61).

Most frequently the problems occur, when the modality of the category of truth from compliance with the reality (practical, scientific) to axiological (truth about the object as about the good and its value) or ontological (what the value of object is) forms is faced. The latter serves in the empiric plane as a methodological substantiation, which is rooted in conscience, which is said to be the voice of God in an individual. The axiological truth spreads in the moral plane, allowing to evaluate the familiar reality from the perspective of the good and bad. Its content embraces the most relevant values (statements, principles) related to appropriate behaviour but it is not restricted to this only and expands through transcendentalities (truth, beauty, good), which are close by their abstraction from other specific objects, which were ascribed to the ideal sphere by Plato, enables to 
see the personal relations to the reality from a multi-sided perspective, when "some are linked to the sphere of theoretical cognition and theoretical truth, others are related to the sphere of arts and beauty" (Wojtyła, 1997, p. 205). Therefore, it is clear why A. Maslow (1997) refers to them as values of the Being and compares it with reflections of one beam on the edges of a gemstone, highlighting their internal coherence, whereas K. Wojtyła sees transcendentalities as "covering experience of personal transcendence" (Wojtyła, p. 204). But even in scientific texts there appear cases of narrowing the content of spiritual values, when only religious values are often regarded as spiritual, when spiritual, moral, aesthetic and other values are used synonymously, which distorts their meaning. Having evaluated such attitudes, A. Rodger (2000) rhetorically asks if such concepts as cutlery, knifes and forks may be considered synonyms. It should be pointed out that according to the authors, whose transcendentalities of the authors, who envisage invariable origin of a human being, make up the basis of Eternal values, which allows to understand the meaning of heritage of cultures from various epochs and to identify the same problems is contexts of different cultures.

To determine spirituality, it is important to understand external expression of its modality. It is significant because even failing to determine spirituality at theoretical level, spiritual people are easily recognised in the empiric plane: they are distinguished by this internal and hardly verbally articulated attractiveness, power, prominence, honour, light..., which surpass confessional, ideological, political, social and other differences (e.g., Mother Theresa, John Paul II, Dalai Lama and others) and are sometimes ascribed to charisma and vocation. Though authentic relations of such people differ in their content, ways of expression, etc., love is the common denominator (to truth of Thomas More; to humanity of priest Kolbe, who chose death instead of the father of a large family; to beauty of a destitute artists, who refused to create kitsch, teacher's altruism to learners, embodied by both scholars of pedagogy (Pestalozzi, Korchak, etc.) and by a big number of ordinary teachers, who have been carrying out their mission with love).

Love, as widely experienced phenomenon, is discussed by researchers on human phylogenesis and ontogenesis. Only it is observed and felt externality frequently presupposes superficiality of opinions, when the spiritual essence of love is disregarded and only psychical or physical expression becomes relevant. However, such attitudes reflect the importance of love in people's lives, whereas failure to determine it directs towards spiritual origins of love in specific way: the integrating power of the soul is most obviously manifested subjugating psychical and corporal powers. The more mature the soul, the stronger the integration is. Moreover, according to, K. Wojtyła, namely through experiencing the spirituality acquires the experiential inside of its existence and activity. Love as the supreme form of experiencing human relations, mostly reveals the maturity of spirituality because the ontological meaning of love to bigger or smaller extent is highlighted, which diverts us towards its unnatural origin (“...God is love” (1 John 4:8)); building the road to Eternity ("Love never ends" (1 Cor 13:8)); it is perceived as the most 
important precept (“This is my command: Love each other!” (John 15:17)). It is obvious that love-based relations are namely the most obvious signs of positive becoming of a human, which integrate all the powers for the truth of being, laying in conscience, to freely embody and present oneself. It is simultaneously noticed that seeking for love, which starts as early as infantry, does not lose its importance throughout life, though its forms vary and, according to J. Pieper, turn strangers into their very own.

While searching for the contour of spirituality, it is important to emphasise the anti-natural origin of the soul. According to the opinion of the aforesaid neurophysiologist and psychiatrist V. Frankl, "an individual cannot pass down personality, personal spirit and spiritual existence" (2007, p. 336), whereas "the soul, the spiritual personality itself cannot fall ill at all” (2007, p. 337). From this perspective, a person is considered to be a non-reflecting being: he or she may cognise himself or herself but not the self-cognition itself. Therefore, the most mysterious origins of conscience extend beyond the unrealised sphere of the subconscious, pre-moral perception of a value, which allows to sense and show, what should occur. The origin of the soul for the researchers, who follow principles of materialism and pragmatism, exceeds the boundaries of their research field and, therefore, they tend to reject it or perceive it as public conscience, the real essence, etc. not linking it with fundamental dimension of an individual.

Interwoven individual's psychical and spiritual powers are complicated because they penetrate into the internal world of an individual and are interlinked. However, it is known "that "spiritual" powers are not equal to "psychical" ones" (Wojtyła, 1997, p. 279), while "projecting a human from spiritual space, where he, actually, "is present" to psychical as well as physical plane, we lose not just one dimension but namely the human dimension" (Franklis, 2007, p. 346). The assumption that spiritual is not equal to psychical is supported by other contemporary authors: R. S. Covey (2007) states that namely the soul predetermines functioning of psychical and corporal dimensions; M. Rupnik (1997) argues that linking of the spirituality only with psychical qualities (intellect, feelings, volition), may remain coincident with manifestations of agnosticism, sentimentality or voluntarism. The identification of the spirituality, when identified only with non-materiality, directs it towards entrenchment of ephemerality and ambiguity. However, this division (psychical and spiritual powers) does not attract the focus of any in-depth studies due to its possible "scientific" intangibility. It is also hardly escalated in the public space and even from tautological perspective, the soul is perceived as "an activity incentive of psychical human power" (Contemporary Dictionary of Lithuanian Language), whereas psyche is regarded as "an aggregate of inborn and acquired spiritual qualities (intellect, feelings, volition) of a human being and other animals possessing refined nervous system; the soul, spiritual life" (Dictionary of International Words). Such situation impedes understanding of the becoming of an individual as well as provision of competent educational support.

Insufficient understanding of the content of spiritual values also hampers educational processes. Frequently only religious values are perceived as spiritual ones. Such 
assumption may have been influenced by linking of spirituality to the supreme good and intangibility. However, such attitude is one-sided and fails to exhaust content of spiritual values. Even in religious texts fiends and demons are active. Moreover, spirituality of a number of religious people may be very low and not in accordance with the laws of God and people. According to Kurtz \& Ketcham, "the raised question is not whether we have spirituality but whether the spirituality we posses is negative and leads to isolation and self-destruction or rather the one, which is positive and providing with life" (cited in Phelps, 2006). It should also be stated that Christianity approaches the evil as the undeveloped good. This allows to reject the idea of inborn evil and opens up methodological approaches to educational processes, when evoking of spirituality is possible among people from various confessions or free thinkers because the power to transcendent the reality, which ensures free (authentic) determination and its links with conscience as with the source of the true, is followed.

Determining the contour of spirituality, the content of spiritual values is linked with transcendentalities, taking into account that they have enabled people to envisage the most important aspects of the spiritual reality, which mainly embody the spiritual beginning of the human being since ancient times, when a human being was not regarded as a person. It is obvious that in separate cultures some differences in expression were formed though their fundamental essence remained. As it was accurately noticed by A. Maslow, "culture is sun, food and water; it is not a seed", which existed as early as embryo stage but establishes conditions (encourages, fosters and supports) for its (seed's) becoming real and topical or in modern language, for socialisation (2011, p. 245).

Even having approached the human origin from a distance, having deeper penetrated into the spiritual dimension, it is possible to determine the framework of spirituality as spread of spiritual dimension. Following the research by other scientists (Aramavičiūtè, 2005; 2009; Jovaiša, 2011; Rupnik, 1997 and others.) earlier (Martišauskienè, 2004) and continuing research carried out by the author, authentic relations of an individual with the world, which penetrate in the whole being with love, true, beauty and extends towards the Creator are considered to be characteristic of spirituality.

Such understanding implies a free determination, reveals the contour of spirituality of content, ontological roots of spirituality and its perspectives, which meld the main parameters of liberty, true and love.

\section{Deep link of adolescents' spirituality and socialisation}

Though socialisation predetermines the fate of all the life of an individual, in each developmental period it acquires specific features and problems. Adolescence performs a specific role here because its main characteristic is search for identity (Eriksonas, 1996). This means that it is not enough to accept opinions or decisions of others but a young 
person has to search for answers not only to outlook-related questions what the world is like but also who $I$ am and to make attempts to search for solutions in tough situations (which are numerous) and to make decisions. For this reason the adolescent crisis has been widely acknowledged and has become a social problem, when delinquent behaviour starts to emerge, which to big extent is an outcome of social environment. However, an adolescent frequently fails to understand and the society does not even seek to understand it because then they would have to assume responsibility.

From the educational perspective, the adolescence problems derive from unequal development of physical, psychical and spiritual powers. Changes in physical powers are most obvious to adolescents themselves as well as to surrounding people and create prerequisites for considering young people adults, particularly in new situations naturally evoking the so-called "sense of maturation". Physiological changes presuppose new senses and experiences and their scope expands. Not only wisdom is needed to understand them but also an ability to manage the growing powers but these already embrace functions of other dimensions of an individual. In fact, psychical ones are necessary first of all.

Only if physical powers of a human being develop according to natural laws, which are obeyed by any living organism regardless their will or willingness to realise own genetic rudiments, development of psychical powers is already based on certain circumstances, which only partially are predetermined by physiological changes. It is known that all the psychical processes may completely function in adolescence; therefore, the range of cognition, feelings, volition and others tends to increase. However, it is far from equal because it depends on inborn rudiments as well as on external circumstances and socialisation and (self-)education in particular. The latter are hardy separable aspects as reliable methodologies to establish their overlapping as well as to localise reasons of deprivation, to adequately evaluate achievements, which have considerable effect on the becoming of a personality are not available. On the other hand, the balance of spread of cognitive and physical powers are relevant for understanding and managing of own changes, that is , development of cognitive powers is sufficient not to build up perversion of physical powers. The number of problems increases when the doors to self-awareness open, which enable the deepening effect of spiritual dimension.

As it has been mentioned above, spread of psychical dimension creates prerequisites to adolescents "to posses oneself", that is, to understand oneself and own powers, and to direct oneself and own powers towards the desired direction, in other words, to develop relations. Relations are an essential mark of a human as a spiritual being because they prove the existence of the inner, that is, "ability to have a relation and to engage into the relation" (Pieperis, 1992, p. 23). Their importance is huge as early as birth, only in earlier periods of developments adults are initiators of relations and responsible for them. The challenge of adolescence as a period of entering self-dependent life is authentic relations firstly with peers because such relations enable a young person to self-realise best and to equally relate to the surrounding world. This process is considered to be successful, when 
the relations are based on spiritual values that model the connection of psychical and physical powers pursuing meaningful goals. The primate of spiritual values is predetermined by their supernatural origin, the phenomenon of the true behind consciousness, which eliminates syndromes of competition, power and pleasures from relations.

Problems of adolescents' socialisation are sharpened by a number of issues. One of them is related to the level of cognitive powers because the extent to which an individual is able to perceive the essence of objects predetermines the depth of his or her relations to them. It should be pointed out that the essence does not show up in the surface of objects or phenomena, whereas easy access to information of various level enhances the superficial understanding and weakens efforts to deeper perceive them. Observation of separate features (opinions, trendy clothes, hairdos, language, posture, etc.) starts to prevail, what presupposes fragmented nature of relations. Adolescents express willingness to have real friend/s, who would allow them to feel spiritual unity and inner closeness, to unclose, to link own future perspectives just as to understand oneself and the Self. Both are closely related "as an individual identifies own uniqueness and absoluteness only in relation with another individual - in the presence of another" (Laumenskaite, 2006, p. 3). Increasing opportunities of adolescents to expand the field of relations, there remains a necessity to verify adequacy of own attitudes, feelings and actions towards understanding or sensing of others because they (other people) serve as a mirror, which is used to see the Self. When relations fail to develop, a virtual space is a frequent solution to the problem, where similar people meet and, thus, eliminate environmental interferences; however, the evangelical truth annunciates that "if the blind lead the blind, both shall fall into a pit” (Mt 15:14). Therefore, the path while searching for identity is very painful to the majority because it embraces both the origins of inborn psychical and physical powers and experiences of socialisation, the former and the current relation of the others with them.

It is important to draw attention that identity, according to A. Giddens, is " $<\ldots$. the self as reflexively understood by the person in terms of her or his biography" (Giddens, 2000 , p. 74), or in K. Wojtyła's words, it is a meaningful unity, which does not ignore experiential richness and diversity, is formed on the basis of values, is rooted in sensing of self-esteem and human dignity, whereas the expression of identity is analysed from various aspects. According to the processes of self-regulation (Kerpelman, etc. 1997), interpersonal and intrapersonal levels of identity are distinguished, which embrace self-perception and comparison with accepted standards of identity. On the basis of maturity, four identity statuses may be pointed out (Marica, 1980): diffusion, foreclosure, moratorium, achievement, which overlap with each other. Though identity statuses may simultaneously be at different levels in various spheres, they are always firstly associated with original identity related to existential fundamentals of life such as family, gender, religion, nation, etc., which provide meaning to personal life to greatest extent and, thus, ensure its integrity as characteristic of all individuals. 
Problems increase because relativism shakes the fundamental values as well as foundations of socialisation, which under processes of globalisation may crystallise into fundamentalisms or lose own value eliminating the voice of conscience. It is important to emphasise that these processes penetrate into the real and virtual space, into families, education institutions to prepare a new generation of consumers, who follow market laws. Such confusion causes problems to adults, whereas it becomes a natural reality, when even higher abilities or aspirations create obstacles and prevents from feeling safe and accepted by peers. The researchers have already been carrying out research on the changes in values of the so-called $\mathrm{Z}$ generation; however, this generation has only been growing fruit and their maturation is still in future.

It is necessary to understand that the opinion stating that the current generation is different (it has been since ancient times) has been regularly escalated as well as the thought that previous experiences are not appropriate for it and technological changes result in radical changes in the new generation. It should be emphasised that such situation does not change the essence of individuals but possibilities of socialisation, which are different from the ones familiar to parents and grandparents. Therefore, the latter are not understandable and, naturally, unacceptable to them. Rapid development of environment impedes the processes of socialisation, more highlighting the lack of fundamental aspects, which promote humanity. The fact that a big number of individuals think or act in a similar way if not in the real then in virtual space, provides individuals with a temporary sense of safety (I am like others) but the lie disseminated by the whole world cannot turn into the truth without which not only external but also internal harmony is hardly possible.

Problems of adolescents' socialisation, which are mainly interdisciplinary, attract the attention of researchers, who reveal the impact of various factors (gender, inheritance, social status, education, culture, experience, etc.). For example, the big project 'Adolescent', under supervision of R. Bibby, was implemented in Canada in 2008 and it highlighted dynamics of 15-19 year old young people's attitudes, values, beliefs and expectations. The acquired data were compared with the results of the previously conducted research (1984, 1992 and 2000). The improving attitude of adolescents towards school and learning was observed because as many as 7 out of 10 respondents would like to obtain higher education diploma; moreover, the importance of relations with peers remained significant because the majority of the respondents $(94 \%)$ pointed out that at least one of the closest friends learnt in the same school. The research showed that cultural differences influence subordination of values. At the end of the 20th century Cyril Simmons conducted research in adolescents from five cultures (Great Britain, USA, Saudi Arabia, Israel, Japan), which revealed that British and American adolescents prioritise family and friends. On the other hand, Japanese and partially Israeli adolescents ranked science and education highest, whereas young citizens from Saudi Arabia unanimously prioritised religion. But this is most obviously expression of the true. The research by T. Lickona and others show that 
fundamental moral things are adopted by representatives of different cultures in a similar ways and, hence, as if confirm in their own way that the phenomenon of conscience id the destiny of human origin, and finally, it is the deepest root socialisation, which should serve as basis for globalisation as a manifestation of humanity.

The research on adolescents in Russia (Vasiljeva) applying the Rokeach Value Survey reveals that 14-16 year old adolescents assign priority to the following terminal values (as final goals): health, happy family, true friendship, mature love, whereas pleasures, happiness of others, social recognition, beauty of nature and arts are least attractive to them. In the group of instrumental values (as means to attain goals) the highly ranked ones include: independence, intellect, joviality, sophistication, and imagination, pride, lenience, self-control are seen as less important. The same research also reveals that about $82.5 \%$ of adolescents see themselves responsible for their own actions. It can be seen that adolescents' relations are modelled in spiritual values in different forms, which frequently real themselves in a fragmentary manner, when such values as true friendship - happiness of others; independence-self-control, etc. are ascribed to opposite poles of choices.

Conducting research on the dynamics of 13-15 year old adolescents' value-based orientations in Lithuania in 1999-2009 also employing the Rokeach Value Survey (Martišauskiene, 2010; 2011; 2013), it was revealed that in 1999 the adolescents emphasised the most important terminal values to them health, happy family, true friendship, mature love (the same distribution as in the research by Vasiljeva), whereas they ranked mature love, happy family, true friendship, internal harmony highest in 2009 (Fig. 1.). The most considerable change was observed in the attitude towards internal harmony (threefold increase), in health (twofold decrease), mature love (almost twofold increase), however, acknowledgement of family as a value considerably decreased. Least attractive values in 1999 included: pleasures, creation, national security and beauty. After the decade evaluation of salvation (fourfold decrease) received lowest ranking as well as pleasures, social security and beauty. Therefore, it can be stated that moral values, which embody relations with relatives, are important to Lithuanian adolescents. However, esthetical values, which give sense to the being at supreme level through sensation of beauty and creation as well as salvation or open hedonism and national security remain irrelevant.

The adolescents ranked honesty highest (Fig. 2.) among instrumental values in the research conducted in 1999. The evaluation of sophistication, politeness, responsibility was ten percent lower, whereas in 2009 altruism, responsibility, honesty and forgiveness were evaluated higher. It shows that the vector of choosing values is also directed toward increase in significance of moral values. The biggest positive change was observed in acknowledgement of altruism, whereas the importance of honesty decreased. The respondents considered pride, imagination, obedience and broad-mindedness least acceptable (most frequently ranked lowest) in 1999. Such tendencies remained after ten years as well, only the negative attitude towards obedience, cleanliness strengthened significantly, whereas attitude towards imagination decreased by five percent. It can be 
stated that values, which promote esthetical relation, are not considered priorities. It is difficult to believe in the depth of understanding of altruism, forgiveness and responsibility, when acknowledgement of their roots, i.e., honesty, has been decreasing. On the one hand, this shows fragmentary and lower stages of formation of adolescents' identity; on the other hand, it reveals the emerging direction of relations based on moral values, the aspiration, which may be attained only through sense of the depth of spiritual values. As long as these relations are directed only towards current or expected personal contacts and simultaneously fail to penetrate into spheres of cognition and beauty, processes of socialisation mainly depend on external circumstances and are not able to ensure full individual's involvement in social life to comprehensively improve it, in other words, own aspirations to link with lives of other people and finally with problems of humankind. If the search for identity generally looses touch with spiritual values, the foundations for socialisation also disappear. The individuals, who fail to establish real personal contact submerging into the virtual space, find themselves in complicated situations. Therefore, the pedagogical problems remain.

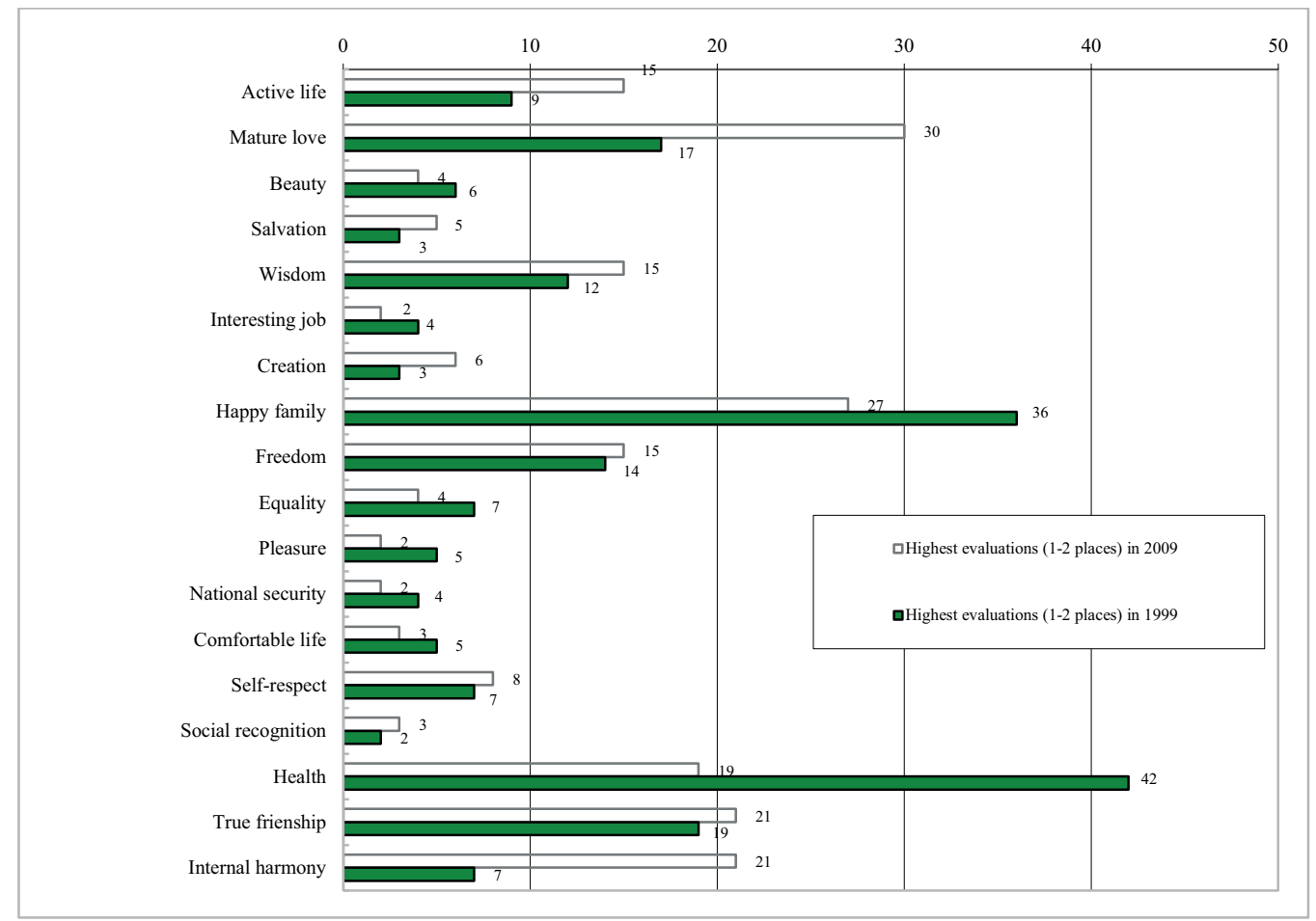

Fig. 1. Dynamics of adolescents' attitude towards terminal values (1999-2009) 


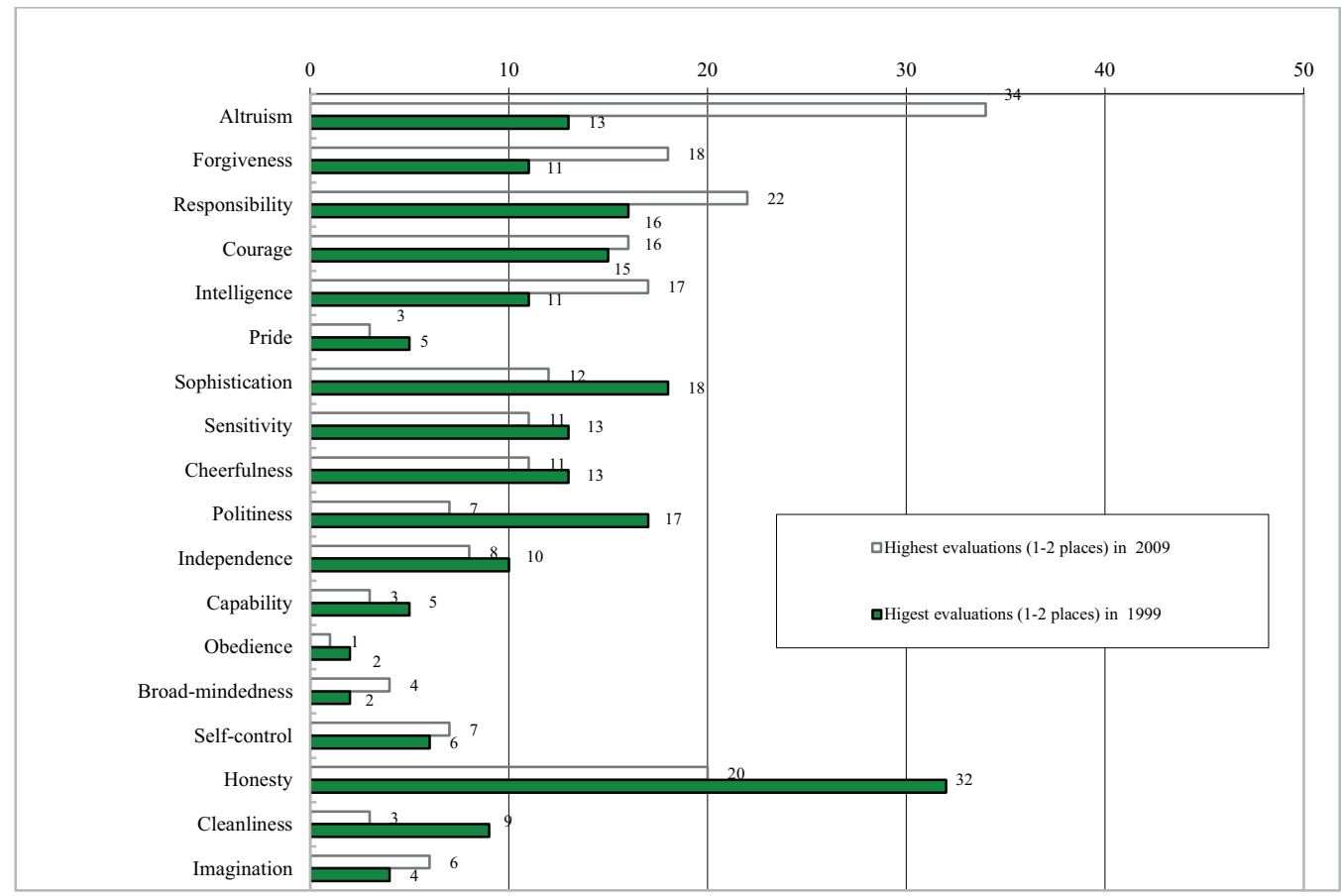

Fig. 2. Dynamics of adolescents' attitude towards instrumental values (1999-2009)

In its essence education is always connected to socialisation and, according to A. Juodaityte, should be considered as "a specific kind of socialisation" or as "planned socialisation" (2002, p. 127, 130). On the one hand, it refers to the whole content of education, to that "part of experience, which has already been tested and generalised through mutual communication in social groups" (ibidem, p. 130). On the other hand, this is a live process, where such relations as a teacher-learner, learners; a learner - a learner; a learner-parents and others evolve. As theory and practice show that the latter (relations) contribute to giving sense to regulated education content, deepen sensation of own honour and authenticity. Therefore, it is understandable, why J. Raven, a psychologist from Edinburgh, reminds us that "spiritual or transcendental dimension $<\ldots>$ has to make up an integral part of all the research and to focus on study subjects" (1999, p. 48). And not only of all the research but also of education because socialisation is undoubtedly based on relations and their success is predetermined by values functioning in the institutionalised and natural reality. If due to certain circumstances, the internationalisation of spiritual values of adolescents is of low level, hampers, or if socialisation processes and building up of positive identity acquire perverse forms, then together with Maslow we have to ask what society, education, psychotherapy, family should be like, to make an individual, who makes "choices in favour of supreme values, to be considered as a "good" one" (1997, p. 160). Naturally, the focus should be laid on education emphasising not only formal 
achievements of learners but also their positive meaning in the classroom setting, school community and region, integrating the most important actors and factors of education.

\section{Conclusions}

Occurring processes of globalisation contribute to broadening of the horizons of socialisation, which establishes new opportunities and problems that firstly affect adolescents, who make attempts to consolidate their position in contemporary society.

Socialisation, as a global phenomenon, is related to human origin. Therefore, to understand socialisation processes, to manage them, it is necessary to identify possibilities of human origin and its structure. This is a complex activity because individual's internal world is entered, whereof essential parameters are not accessible to scientific cognition. This also impedes capture of socialisation processes.

More and more researchers in various spheres of sciences perceive a human being as an aggregate of physical, psychical and spiritual components. Spiritual powers based on transcendence and consciousness empower free determination and links of these decisions to the true, that is, presuppose authentic value-based relations with environment and the self. In such cases psychical and physical powers become personal tools, whereof quality has an impact on expression of relations and formation of identity.

The processes of socialisation are particularly complicated because there frequently occurs an imbalance of development of individual's physical, psychical and spiritual powers. If physical powers obey determinism of nature and are often obvious and measurable, natural rudiments and their spread in the individual's ontogenesis intertwine in psychical ones. Both have a big influence on results of activities and relations as well as on processes of socialisation. There emerges a problem that they are not directly measured, therefore they cannot be adequately evaluated even by adults, whereas adolescents experience difficulties evaluating others and themselves. Spiritual powers unfold even in a more complicated way fed by love and due to their essence and expression get to the epicentre of relations and, consequently, socialisation, which concentrates on search for identity in adolescence. When they encounter obstacles in real situations, the relations of adolescents start developing in the virtual space.

Since relations develop on the basis of values, adolescents' value-based orientations manifest prerequisites for their socialisation. The research conducted in Lithuania and all over the world allows to conclude that adolescents most frequently concentrate on moral values, cognitive values are ranked in the middle, whereas esthetical values are considered to be least relevant. Moreover, it can be concluded that such factors (cultural, social, gender and others) have effect on internationalisation of spiritual values. This has to be considered organising the process of education as a link to institutional socialisation. 
Adolescents' education, as a planned socialisation, has to be directed towards strengthening of spirituality to promote choices of supreme values and to establish conditions for positive evaluation of such choices.

\section{References}

Aramavičiutè, V. (2005). Auklejimas ir dvasinė asmenybės branda. Vilnius: Gimtasis žodis. Aramavičiute, V., Martišauskienè, E. (2009). Dvasingumo raiškos kontūrų beieškant. In Dvasingumas žmogaus pasaulyje. Collective monograph. Vilnius: Vilniaus pedagoginio universiteto leidykla, 88-103.

Biblija, arba Šventasis Raštas. Ekumeninis leidimas. (2005). Lietuvos Biblijos draugija, Vilnius.

Bibby, R. (2012).Views of Adolescence: Socialization and Development. [Online]. Available online at: http://www.mheducation.ca/school/files/2012/04/Challenge-and-Change-Chapter-1-3rdpass-1-WATERMARKED.

Collins, F. S. (2008). Dievo kalba: mokslininkas liudija tikejjimo į Dievą pagrįstumą. Vilnius: Katalikų pasaulio leidiniai.

Covey, R. S. (2007). 8-asis ịprotis: tobulybès link. Vilnius: Alma littera.

Covey, R. S. (2006). 7 sékmés lydimų žmonių ịpročiai: charakterio etikos rekonstrukcija. Kaunas: Mijalba.

Dabartinés lietuvių kalbos žodynas. (2011). Vilnius: Lietuvių kalbos institutas, 2006 [Online version]. Available online at: http://dz.lki.lt.

Einšteino mintys. (2002). Compiled by A. Calaprice. Kaunas: Verba vera.

Frankl, V. (2007). Dešimt tezių apie asmenybę. In Sielogyda. Gydytojo rūpestis sielą. Dešimt tezių apie asmenybę. Vilnius: Vaga, 335-346.

Giddens, A. (2000.). Modernybe ir asmens tapatumas: asmuo ir visuomenè vélyvosios modernybès amžiuje. Vilnius: Pradai.

Jokubaitis, A. (2012). Vertybių tironija ir politika : [monograph]. Vilnius : Vilniaus universiteto leidykla.

Juodaitytè, A. (2002). Socializacija ir ugdymas vaikysteje.Vilnius: Petro ofsetas.

Jovaiša, L. (2011). Edukologija: rinktiniai raštai. Vilnius: Agora.

Kande, D. B. (1978). Homophily, Selection, and Socialization, In: Adolescent Friendships. New York State Psychiatric Institute and Columbia University Institute and Columbia University [Online]. Available online at: http://www.jstor.org/discover/10.2307/2777857?uid=3738480\& uid=2129\&uid=2\&uid=70\&uid=4\&sid=21104606538233American Journal of SociologyVol. 84, No. 2, Sep., 1978.

Kerpelman, J. L., Pittman, J. F., Lamke, L. K. (1997). Toward a Microprocess Perspective on Adolescent Identity Development: an Identity Control Theory Approach. Journal of Adolescent Research, 12, 325-346. 
Laumenskaitė, I. E. (2006). Kaip igyvendinti bažnyčios socialinį mokymą? [Online] [Accessed 8 December 2013]. Available online at: http://www.bernardinai.lt/straipsnis/2006-09-21nutylima-tema-irena-egle-laumenskaite-kaip-igyvendinti-baznycios-socialini-mokymaii/5043.

Lobato, A. (2001). Žmogaus orumas ir likimas. Vilnius: Logos 1-kla.

Lickona, T. (1991). Educating for Character: How Our Schools Can teach Respect and Responsibility. New York-Toronto-London-Sydney-Auckland: Bantam books.

Marica, J. E. (1980). Identity in adolescence. Handbook of adolescent psychology. New York: Wiley. Martišauskienė, E. (2004). Paauglių dvasingumas kaip pedagoginis reiškinys. Vilnius: VPU leidykla. Martišauskienè, E. (2011). Paauglių požiūris ị dvasines vertybes: kaitos tendencijos.

Acta paedagogica Vilnensia: research papers, 27, 43-54.

Martišauskienè, E. (2010). Paauglių savęs vertinimo sklaida ir kaitos tendencijos reformuojamoje mokykloje. Pedagogika: research papers, 100, 64-71.

Martišauskienè E. (2013). Šiuolaikinių paauglių dvasinių vertybių pajautos dinamika edukaciniame kontekste. Acta paedagogica Vilnensia: research papers, 30, 73-82.

Maslow, A. H. (2011). Büties psichologija. Vilnius: Vaga.

Pieperis, J. (1992). Kas yra filosofija. Vilnius: Katalikų pasaulis.

Phelps, D. (May 2006). Understanding the Spiritual Lives of Adolescents. Presented at the First North American Conference on Spirituality and Social Work.

Rodger, A. (2000). Moral, Spiritual, Religious - Are They Synonymous: Education, Culture and Values. Ed. by M. Leicester, C. Modgil and S. Modgil. London and New York, 5, 3-14.

Rupnik, M. I. (1997). Nesudegančio erškètyno liepsnoje. Dvasinio gyvenimo pradmenys. Vilnius: Aidai.

Wojtyła, K. (1997). Asmuo ir veiksmas. Vilnius: Aidai.

Эриксон, Э. (1996). Идентичность: юность и кризис. Москва: Прогресс.

Каган, М. С. (1988). Мир общения. Проблема межсубъективных отношений. Москва: Издательство политической литературы.

Маслоу, А. (1997). Дальние пределы человеческой психики. Санкт-Петербург: Евразия.

Равен, Д. (1999). Педагогическое тестирование: проблемы, заблуждения, перспективы.

Москва: Когито Центр.

Tarptautinių žodžių žodynas [Online]. Available online at: http://www.zodziai.lt/. 


\title{
Dvasingumas kaip paauglių socializacijos pamatas: metodologinès prieigos
}

\author{
Elvyda Martišauskienè
}

Lietuvos edukologijos universitetas, Ugdymo mokslų fakultetas, Edukologijos katedra, Studentų g. 39, 08106 Vilnius, martisauskiene@gmail.com

\section{Santrauka}

Straipsnyje metodologiniu aspektu aptariamos socializacijos problemos, kurios ypač aktualios paauglysteje, nes glaudžiai siejasi su svarbiausiu vyksmu - tapatumo paieška, kuri dèl globalizacijos procesų tampa sudètingesnè.

Socializacija, kaip visuotinis reiškinys, yra susijusi su žmogaus prigimtimi, o jos esminiai parametrai pozityvizmu grindžiamam mokslui yra neprieinami. Tai sunkina ir socializacijos procesų pagavą.

Vis daugiau įvairių sričių mokslininkų žvelgia ì žmogų kaip ị fizinių, psichinių ir dvasinių dèmenų sampyną. Joje dvasinès galios, besiremiančios transcendencija ir sąži$n e$, suponuoja autentiškus vertybinius santykius su supančia aplinka ir savimi. Tuomet psichinès ir fizinės galios tampa asmens įrankiais, kurių kokybė daro poveikị santykių raiškai ir tapatumo formavimuisi.

Paauglysteje socializacijos procesai yra sudètingi, nes dažnai susidaro disbalansas tarp asmens fizinių, psichinių ir dvasinių galių raidos, dèl ko paaugliai patiria itin daug sunkumų vertindami kitus ir save. Kai stringa santykiai realiose situacijose, pagrindiniu socializacijos šaltiniu tampa virtuali erdvè.

Kadangi santykiai klostosi vertybių pagrindu, vertybinès orientacijos rodo socializacijos ištakas: paaugliai daugiausia telkiasi ị dorovines vertybes, pažintinès vertybès patenka ị vidurio poziciją, o mažiausiai reikšmingomis laikomos estetinès. Be to, aiške்ja, kokie veiksniai (kultūriniai, socialiniai, lyties ir kt.) daro poveikị dvasinių vertybių internalizacijai.

Esminiai žodžiai: paauglys, socializacija, tapatumo paieška, žmogaus dimensijos, dvasingumas, vertybès. 